\title{
Insulin acts via mitogen-activated protein kinase phosphorylation in rabbit blastocysts
}

\author{
Anne Navarrete Santos, Sarah Tonack, Michaela Kirstein, Marie Pantaleon ${ }^{1}$, Peter Kaye ${ }^{1}$ \\ and Bernd Fischer \\ Department of Anatomy and Cell Biology, Martin Luther University Faculty of Medicine, Grosse Steinstrasse 52, \\ D-06108 Halle (Saale), Germany and ${ }^{1}$ School of Biomedical Sciences, The University of Queensland, Brisbane, \\ Queensland 4072, Australia
}

Correspondence should be addressed to B Fischer; Email: bernd.fischer@medizin.uni-halle.de

\begin{abstract}
The addition of insulin during in vitro culture has beneficial effects on rabbit preimplantation embryos leading to increased cell proliferation and reduced apoptosis. We have previously described the expression of the insulin receptor (IR) and the insulin-responsive glucose transporters (GLUT) 4 and 8 in rabbit preimplantation embryos. However, the effects of insulin on IR signaling and glucose metabolism have not been investigated in rabbit embryos. In the present study, the effects of $170 \mathrm{nM}$ insulin on IR, GLUT4 and GLUT8 mRNA levels, Akt and Erk phosphorylation, GLUT4 translocation and methyl glucose transport were studied in cultured day 3 to day 6 rabbit embryos. Insulin stimulated phosphorylation of the mitogen-activated protein kinase (MAPK) Erk1/2 and levels of IR and GLUT4 mRNA, but not phosphorylation of the phosphatidylinositol 3-kinase-dependent protein kinase, Akt, GLUT8 mRNA levels, glucose uptake or GLUT4 translocation. Activation of the MAPK signaling pathway in the absence of GLUT4 translocation and of a glucose transport response suggest that in the rabbit preimplantation embryo insulin is acting as a growth factor rather than a component of glucose homeostatic control. Reproduction (2004) 128 517-526
\end{abstract}

\section{Introduction}

Insulin and insulin-like growth factors (IGF)-I and -II mediate mitogenic, anti-apoptotic and anabolic effects in mammalian preimplantation embryos. Early embryos express all three receptor subtypes and the ligand for IGFII. Whilst IGF-I expression has been demonstrated in mice, sheep and bovine embryos (Schultz et al. 1992, Kaye 1997), insulin is not expressed by any species studied to date. Insulin and IGF-I are found in the oviduct and uterine lumen during the pre- and peri-implantation period (Lighten et al. 1998, Chi et al. 2000). Thus, the embryo either expresses these growth factors itself or has access through genital tract secretions, implying that functional autocrine, paracrine and/or endocrine insulin/IGF circuits are operating during early development. The intracellular mechanisms by which the hormone signal is transduced following receptor binding and the induced cellular reactions, however, have not been studied in detail so far.

Whilst both the insulin receptor (IR) and IGF-I receptor (IGF-IR) are type 1 tyrosine kinase receptors, the type 2 IGF-II receptor (IGF-II-R) contains binding sites for a number of other ligands including mannose-6-phosphate and retinoic acid, and has multiple functions depending on the binding domain that is activated. IGF-II binding to the type 2 receptor is thought to promote differentiative development in the early embryo (Pantaleon et al. 2003). Structural similarities between insulin and IGF-I allow each ligand to bind to both type 1 receptors but with a more than 100 times greater affinity for its homologous receptor. In rabbit embryos IR expression is first apparent in the early blastocyst (Navarrete Santos et al. 2004) whilst IGF-I binding is seen from the morula stage (Herrler et al. 1998). The rabbit IR sequence shows a high degree of identity to the human IR type $A$ and to IR of various other mammalian species with conserved tyrosine phosphorylation sites (Navarrete Santos et al. 2004).

The IR/IGF-IR signaling involves two major pathways, the mitogenic-activated protein kinase (MAPK) and the phosphatidylinositol 3-kinase (PI3-K) pathway. The mitogenic response, mediated via the interaction of Grb2, SOS and RAS, leads to the activation of the extracellular signal-regulated kinase (Erk) which, in turn, regulates several transcriptional events involved in mitogenesis. Activated Erks, for example, mediate the growth-promoting effects of insulin by phosphorylating transcription factors such as ELK-1 (for review see Le Roith \& Zick 2001). 
Metabolic responses to insulin are primarily mediated via the PI3-K pathway. Following association of the p85/p110 complex of the PI3-K with insulin receptor substrate molecules, PI3-K activates phosphoinositol 3,4,5-phosphate $\left(\mathrm{PIP}_{3}\right)$, which binds to and activates the PI3-K-dependent kinase-1 (PDK-1) and Akt (protein serine/ threonine kinase $\mathrm{B}$, also referred to as PKB). The stimulation of glucose transport, glycogenesis and protein synthesis are key metabolic effects of insulin mediated by the PI3-K/Akt pathway. Akt has been implicated in the translocation of glucose transporter (GLUT) 4 from cytoplasmic storage vesicles (Rea \& James 1997) into the cell membrane in muscle and fat cells (Pessin et al. 1999, Patki et al. 2001).

Glucose is the main energy substrate during blastocyst formation and development in mammals. We have recently shown that two insulin-responsive GLUT isoforms, GLUT4 and GLUT8, are expressed in rabbit blastocysts in a developmentally regulated pattern (Navarrete Santos et al. 2004). These results prompted us to investigate insulin effects on IR signaling and glucose transport in preimplantation embryos of this species. We show that insulin acts on Erk phosphorylation and transcriptional regulation of GLUT4 and IR, but not on translocation of GLUT4 and stimulation of glucose transport in rabbit blastocysts.

\section{Materials and Methods}

\section{Embryo recovery and in vitro culture}

Embryos were collected from sexually mature rabbits stimulated with 100 I.U. follicle-stimulating hormone (Ovagen, Immuno-Chemical Products, Auckland, New Zealand, or Folligon, Intervet, Boxmeer, The Netherlands). Mating, embryo recovery (Navarrete Santos et al. 2000) and embryo culture (Kietz \& Fischer 2003) were performed as described. On days 3, 4 and 6 post coitum (p.c.) embryos were flushed from oviducts or uteri, washed three times with PBS, pooled and randomly divided amongst the experimental groups.

To study the effects of insulin on IR and GLUT4 expression, day 6 blastocysts were cultured in groups of 10 in $500 \mu \mathrm{l} \mathrm{BSM} \mathrm{II} \mathrm{medium} \mathrm{at} 37^{\circ} \mathrm{C}$ in a saturated atmosphere of $5 \% \mathrm{O}_{2}, 5 \% \mathrm{CO}_{2}, 90 \% \mathrm{~N}_{2}$ (Lindenau \& Fischer 1994) in a water-jacketed incubator (BB 6060, Heraeus, Hanau, Germany). Blastocysts were precultured for $2 \mathrm{~h}$ in serum- and insulin-free BSM II medium. Afterwards, $170 \mathrm{nM}$ insulin (Invitrogen, Karlsruhe, Germany) was added to the culture medium and the culture continued for $1,2,3$ or $4 \mathrm{~h}$. Controls were cultured without insulin but otherwise were treated in an identical manner as the treated embryos. IR signaling was analyzed after culture of day 6 blastocysts in the presence or absence of insulin (170 nM, Invitrogen) for 10, 30, 60 or $120 \mathrm{~min}$. For glucose transport studies, morulae (recovered at day 3 p.c.) and blastocysts (day 4) were cultured with or without
$166 \mathrm{nM}$ (morulae, blastocysts), $16 \mathrm{pM}$ insulin (Humulin R, Lilly, North Ryde, Australia, diluted in M2 medium) or 1.3 nM IGF-I (Amersham Pharmacia Biotech, UK) (only day 4 blastocysts) for $1 \mathrm{~h}$ in $100 \mu$ l droplets of glucosecontaining M2 medium (Pantaleon et al. 1997) under oil. Three to nine blastocysts and 6 to 15 morulae were cultured per drop.

\section{RNA extraction}

Preparation of total RNA from embryos was performed using TRIzol reagent (Invitrogen) according to a previously described protocol (Koerber et al. 1998). RNA was treated with DNAse for $1 \mathrm{~h}$. The amount of total RNA was determined spectrophotometrically at $260 \mathrm{~nm}$.

\section{Semiquantitative RT-PCR of IR, GLUT4 and GLUT8 in rabbit blastocysts}

Semiquantitative RT-PCR was performed essentially as previously described (Navarrete Santos et al. 2000, Kietz \& Fischer 2003) with oligonucleotide primers specific for rabbit IR, GLUT4, GLUT8, $\beta$-actin and GAPDH. The IR, GLUT4 and GLUT8 primer sequences were derived from published rabbit (rab) sequences (Navarrete Santos et al. 2004). Two micrograms total RNA were reverse transcribed in a volume of $20 \mu \mathrm{l}$ containing $0.5 \mathrm{mM}$ dNTPs, $10 \mathrm{mM}$ dithiothreitol (DTT), 200 units superscript II, 20 units RNAse inhibitor (Roche Diagnostics, Mannheim, Germany), $1 \mu \mathrm{l}$ random primer and $2 \mu \mathrm{l}$ reverse transcriptase buffer at $42{ }^{\circ} \mathrm{C}$ for $1 \mathrm{~h}$, followed by an incubation at $90{ }^{\circ} \mathrm{C}$ for $5 \mathrm{~min}$. $\mathrm{H}_{2} \mathrm{O}(20 \mu \mathrm{l})$ was added to each cDNA reaction. As a control for DNA contamination, $0.1 \mu \mathrm{g}$ RNA was amplified without preceding reverse transcription. Amplification was carried out with 1 to $5 \mu$ l cDNA in a $50 \mu \mathrm{l}$ volume containing $5 \mu \mathrm{l}$ dNTP, 2.5 units Taq polymerase (Invitrogen), employing the primer combinations: rabIRp1 5'-GCTGGTGGTGATGGAGTTG3'/rabIRp2 5'-TCTCTCTGGACAGTTGTCGG-3'; rabGLUT4p1 5'-GGCGGCATGATTTCCTCC-3'/rabGLUT4p2 5'-GAAGGGCAGCAGGATCAGCT-3'; and rabGLUT8p1 5'-CACGTCAAGGGTGTGGCT-3'/rabGLUT8p2 5'-CAGGGACGCAGAACAAAGTG-3' for IR, GLUT4 and GLUT8 respectively. Primers for $\beta$-actin (actinp $15^{\prime}$-CTACAATGAGCTGCGTGTGG-3', actinp2 5'-TAGCTCTTCTCCAGGGAGGA-3') and GAPDH (GAPDHp1 5'-CGGGAAGCTTGTGATCAATGG-3', GAPDHp2 5'-GGCAGTGATGGCATGGACTG-3) were used to check DNA contamination and quantity of the reverse transcribed mRNA. For all PCR reactions the optimal amplification range was estimated by variation of cycle numbers and cDNA amount (IR: $1 \mu \mathrm{l}$ cDNA, 35 cycles; GLUT4: $2 \mu \mathrm{l}$ cDNA, 38 cycles; GAPDH: $1 \mu \mathrm{l}$ cDNA, 35 cycles). The resulting PCR fragments for GLUT4 (398 bp), IR (497 bp) and GAPDH (507 bp) were separated by electrophoresis on a $1.8 \%$ agarose gel and visualized by ethidium bromide staining. Gels were photographed and the product bands were quantified by densitometric analysis employing the 
software BIO-Profile 1D (LTF-Labortechnik, Wasserburg, Germany). The relative amounts of IR and GLUT4 mRNA were calculated as a ratio of the specific product (for IR or GLUT4) and the housekeeping gene band volume (GAPDH) (Kietz \& Fischer 2003). All PCR reactions were performed at least three times in two independent experiments.

\section{Protein preparation}

Blastocysts were washed three times with PBS after culture and transferred to a $1.5 \mathrm{ml}$ Eppendorf tube. They were homogenized in $100 \mu \mathrm{l}$ cold RIPA buffer (PBS, 1\% NP-40, $0.5 \%$ sodium deoxycholate, $0.1 \%$ sodium dodecyl sulfate $(\mathrm{SDS})$ ) with protease inhibitor cocktail (Sigma, St Louis, $\mathrm{MO}$, USA). The samples were centrifuged at $5000 \mathrm{~g}$ for $10 \mathrm{~min}$. The supernatant was stored at $-80^{\circ} \mathrm{C}$ until use. The total protein content was determined using the BioRAD Protein Assay (Bio-RAD, München, Germany).

\section{Immunoblotting}

Western blots were performed with $25 \mu \mathrm{g}$ total protein from groups of 10 day 6 blastocysts cultured with or without insulin $(170 \mathrm{nM})$ for $10,30,60$ or $120 \mathrm{~min}$. Western analysis was repeated twice in two independent experiments. Equal amounts of protein $(25 \mu \mathrm{g})$ were heated at $100^{\circ} \mathrm{C}$ for $5 \mathrm{~min}$, solubilized in Laemmli buffer containing $200 \mathrm{mM}$ DTT and electrophoresed on a $8 \%$ SDS-PAGE. Proteins were electrotransferred to nitrocellulose membranes. For detection of phospho-Erk1/2, Erk1/2, phospho-Akt and Akt, membranes were blocked in Trisbuffered saline containing $0.1 \%$ Triton $(0.1 \%$ TBST) with $5 \%$ nonfat dry milk at room temperature for $1 \mathrm{~h}$. Blots were incubated in $0.1 \%$ TBST containing $5 \%$ BSA or nonfat dry milk respectively, according to the manufacturers' protocols, with monoclonal antiphospho-Erk $1 / 2$ antibody (1:2000, phospho-p42/p44 MAPK Thr202/Tyr204 E10; Cell Signaling Technologies, Inc., Frankfurt, Germany), monoclonal anti-Erk1/2 antibody (1:2000, p42 MAPK 3A7, Cell Signaling Technologies, Inc.), rabbit-antiphospho-Akt (1:1000, phospho-Akt Ser473, Cell Signaling Technologies, Inc.) and monoclonal anti-Akt (1:1000, Akt 5G3, Cell Signaling Technologies Inc.) at $4{ }^{\circ} \mathrm{C}$ overnight. The phospho-specific activity and the cross-reactivity with rabbit Erk1/2 and Akt were controlled for all antibodies on rabbit liver and heart muscle and on the insulin-treated and -untreated human cell line, MCF7. The antibodies were specific for rabbit tissue. The expected phosphorylation signal was only found in insulin-treated MCF7 cells (see Fig. 1). The rabbit antiphospho-Akt recognized phosphorylated and non-phosphorylated Akt (see Fig. 1A). The Ser473 phosphorylated Akt corresponds with the upper band in Fig. 1A. Only this band was used for calculation (see below). Blots were subjected to three 20-min washes in $0.1 \%$ TBST and incubated for $1 \mathrm{~h}$ at room temperature with anti-mouse (1:20000) or anti-rabbit $(1: 10000)$ IgG conjugated to horseradish peroxidase (Dianova, Hamburg, Germany) in 5\% BSA/TBST. After three 20-min washes in $0.1 \%$ TBST, immunoreactive signals were visualized by enhanced chemiluminescence detection (ECL Plus, Amersham Biotech, Freiburg, Germany) and quantified by densitometry (BIO-Profile 1D, LTF-Labortechnik, Wasserburg, Germany). Apparent molecular weights were determined by comparison with standard molecular weight markers (high range, Promega Corp., Mannheim, Germany). The amounts of Akt and Erk proteins were evaluated by stripping the membranes and re-blotting with non-phospho antibodies. For this the blots were rinsed with $2 \%$ SDS, $60 \mathrm{mM}$ Tris $-\mathrm{HCl}, \mathrm{pH} 6-7$, and $100 \mathrm{mM}$ $\beta$-mercaptoethanol at $50^{\circ} \mathrm{C}$ for $30 \mathrm{~min}$ and re-probed with total Akt and total Erk. As control for the stripping efficiency, the membranes were incubated without adding primary antibody to check that all antibodies had been removed. Protein phosphorylation was calculated as the ratio of band intensities (pAkt vs Akt, pErk1/2 vs Erk1/2) in the same blot in order to correct for differences in protein loading. The relative stimulation of Akt and Erk1/2 phosphorylation by insulin was calculated as the ratio of the phosphorylation signal of insulin-treated and non-treated embryos at each time point. Non-cultured blastocysts $(0 \mathrm{~min}$ in Fig. $1 \mathrm{~A}, \mathrm{~B})$ represent the phosphorylation status of in vitro handled but otherwise untreated in vivo controls. Western blot analyses were performed at least twice in two independent experiments.

\section{Immunohistochemistry (IHC) and translocation of GLUT4}

The GLUT4 antigen was localized on embryonic sections and whole blastocysts. Bouin-fixed, paraffin-embedded day 6 rabbit blastocysts were sectioned at $5 \mu \mathrm{m}$. At least 5 embryos were examined per group. Sections were mounted on silanized slides, deparaffinized in xylene and rehydrated through a series of graded alcohols. For whole mount IHC the paraformaldehyde-fixed blastocysts were rehydrated through a series of graded alcohols. The neozona was removed mechanically before peroxidase blocking. Endogenous peroxidase was quenched by treatment with $3 \%$ hydrogen peroxide in methanol for $30 \mathrm{~min}$. Nonspecific antibody binding was blocked with $10 \%$ normal goat or donkey serum in PBS at room temperature for $1 \mathrm{~h}$ and incubated with the primary antiserum overnight at $4{ }^{\circ} \mathrm{C}$ in a humidified chamber. GLUT4 antibody (mouse anti-GLUT4 antibody 1:2500, DPC Biermann, Bad Nauenheim, Germany) was diluted in PBS with $1 \%$ BSA. Sections and whole blastocysts were rinsed with PBS/0.1\% Tween-20 (PBST) and incubated with the peroxidaselabeled secondary antiserum (DAKO EnVision + /HRPgoat-anti mouse IgG, DAKO, Hamburg, Germany) for conventional light microscopy. The antigen was visualized with the diamino-benzidine (DAB, WAK-Chemie Medikal, Bad Soden, Germany) substrate. The development of DAB was stopped in water after $5 \mathrm{~min}$. Sections were 
A)

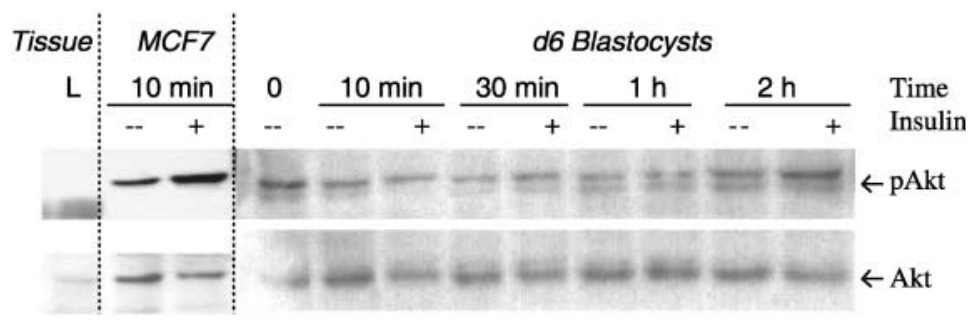

B)
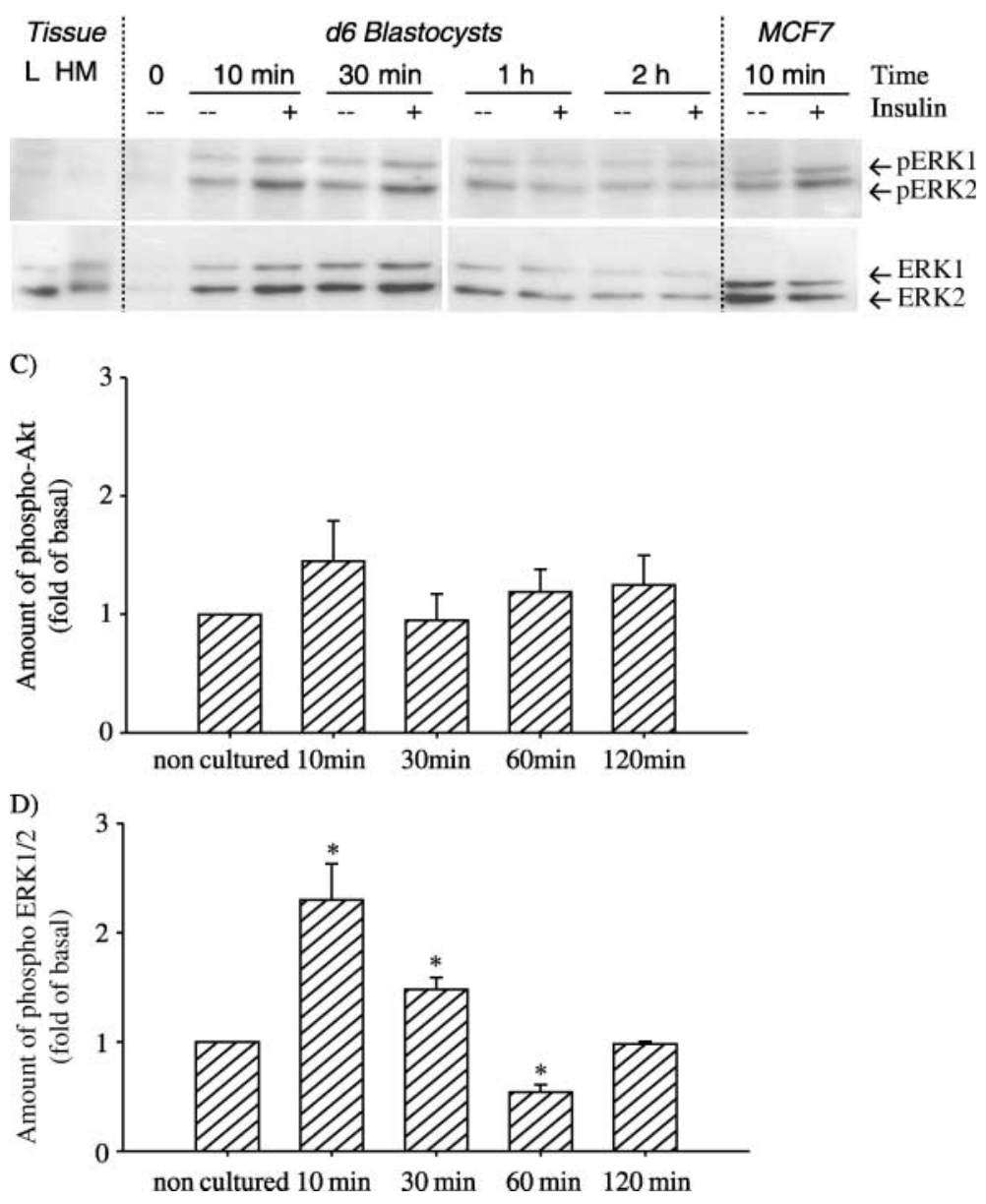

counterstained with hematoxylin, dehydrated and cleared in xylene. The slides were mounted in DPX and examined under bright-field microscopy with an $\mathrm{AH}-3$ microscope (Olympus, Hamburg, Germany). For whole mount confocal microscopy the GLUT4 protein was localized by immunofluorescence detection with the secondary antibody fluorescein (FITC)-conjugated AffinPure donkeyanti-mouse IgG (1:300, Jackson ImmunoResearch Lab., Cambridgeshire, UK). The nuclei were counterstained with 7-amino-actinomycin (7-AAD, DAKO). Whole blastocysts were examined by fluorescence microscopy with Zeiss Axioplan (Zeiss, Oberkochen, Germany). The specificity of immunostaining was demonstrated by the absence of signals in sections incubated with control mouse IgG

Figure 1 Akt and Erk1/2 phosphorylation assays in day 6 rabbit blastocysts. Day 6 (d6) rabbit blastocysts were cultured, in groups of 10, with or without $170 \mathrm{nM}$ insulin for 10, 30, 60 and $120 \mathrm{~min}$. The phosphorylation of Akt and Erk1/2 was analyzed by Western blotting with antiphospho Akt and anti-phospho Erk1/2 antibodies, respectively, in relation to non-phospho anti-Akt and anti-Erk1/2 antibody staining (see Materials and Methods). Representative Western blots for (A) Akt and (B) Erk1/2 are shown. In C (Akt) and D (Erk) the relative stimulation of Akt1 and Erk1/2 phosphorylation by insulin is illustrated (data from two independent experiments; protein phosphorylation in non-treated embryos $=1$ ). Asterisks $\left(^{*}\right)$ indicate significant differences $(P<0.05)$. As references, rabbit liver $(\mathrm{L})$ and heart muscle $(\mathrm{HM})$ and insulin-treated human MCF7 cells were added to the blot and analyzed. Insulin treatment increased Erk1/2 but not Akt phosphorylation.

(DAKO) or in sections processed after omission of the primary antibody. Only reactions with negative controls were included in the study.

\section{Glucose transport studies}

Glucose uptake was measured as described (Pantaleon \& Kaye 1996, Pantaleon et al. 1997). In brief, embryos were washed twice in glucose-free M2 after $1 \mathrm{~h}$ exposure to +/insulin/IGF-I (16 pM or $166 \mathrm{nM}$ insulin, $1.3 \mathrm{nM}$ IGF-I) and transferred into $100 \mu \mathrm{l}$ pulse droplets, kept strictly at $37^{\circ} \mathrm{C}$, for $3 \mathrm{~min}$. The glucose-free pulse medium contained 0.3 mM 3-O-methyl-D- $\left[1-{ }^{3} \mathrm{H}\right]$ glucose $\left(\left[{ }^{3} \mathrm{H}\right] \mathrm{OMG}, 37 \mathrm{GBq} / \mathrm{l}\right.$, Amersham) and $25 \mathrm{mM}$ 3-OMG (Sigma Chemical Co.). 
Uptake was stopped after 3 min by transferring the embryos through four washes of ice-cold glucose-free M2 medium. The diameters of the embryos were recorded using a calibrated ocular micrometer. Radioactivity of individual embryos was determined in a Packard 1600TR liquid scintillation analyzer. In 8 experimental replicates, 56 morulae, 9 early blastocysts and 91 blastocysts were studied. Uptake of 3-OMG is expressed in nmol per 3 min per surface area $\left(\mathrm{cm}^{2}\right)$. The surface area of the spherical blastocysts $\left(4 \pi r^{2}\right)$ was calculated as previously described (Robinson et al. 1990), and used to standardize for the differences in size between 4-day-old rabbit blastocysts. When corrected for the different time of $\left[{ }^{3} \mathrm{H}\right] 3-\mathrm{OMG}$ measurement (3 vs $10 \mathrm{~min})$, these data are in close agreement with those reported by Robinson et al. (1990).

To determine whether the extracellular coverings of rabbit embryos (see Fischer et al. 1991) exerted an influence on glucose transport, the coats of morulae and blastocysts were removed with $0.05 \%$ pronase $\mathrm{E}$ (Herrler et al. 1998) prior to $(170 \mathrm{nM})$ insulin treatment. In total, 30 blastocysts and 6 morulae were studied in two independent experiments. Uptake of 3-OMG was unaffected by insulin treatment in coat-free embryos of both stages $(P>0.05$; data not shown).

\section{Statistics}

Uptake of 3-OMG was analyzed by two-way ANOVA and multiple means range tests using Fisher's protected procedures. Statistical analysis of the GLUT4, GLUT8 and IR RNA levels and the relative stimulation of Akt and Erk1/2 phosphorylation were performed with the paired $t$-test between + and - insulin at the various time points studied (SigmaPlot 4.0, Jandel Corporation (San Rafael, CA, USA) mathematical and statistical analysis). The data are expressed as means \pm S.E.M.

\section{Results}

\section{Insulin does not stimulate the phosphorylation of Akt in day 6 blastocysts}

Active Akt is phosphorylated at Ser473. Western blot analysis with phosphospecific anti-Akt antibody showed that addition of $170 \mathrm{nM}$ insulin for 10 to $120 \mathrm{~min}$ did not alter the level of Akt phosphorylation in cultured blastocysts (Fig. 1A). The antibody used (phospho-AktSer473) detects Akt when phosphorylated at Ser473 (upper band in Fig. 1A). The amount of phosphorylated Akt relative to total Akt was measured in each sample by image analysis. Protein phosphorylation was calculated as the ratio of band intensities (see Materials and Methods). The relative increase in phosphorylation by insulin treatment in comparison with untreated controls was analyzed at each time point (Fig. 1C). Akt phosphorylation was not stimulated by insulin treatment for up to $2 \mathrm{~h}(P>0.05)$.

\section{Insulin stimulates the rapid phosphorylation of Erk in day 6 blastocysts}

Erk-1 and -2 are activated by various cell surface receptors, including tyrosine kinase receptors, receptors coupled to cytoplasmic tyrosine kinase and G proteincoupled receptors. Erk1/2 Western blots from insulin-treated and non-treated blastocysts are shown in Fig. 1B. The amount of phosphorylated Erk-1 and -2, calculated in relation to total Erk, was increased after insulin treatment (Fig. 1D). Addition of $170 \mathrm{nM}$ insulin to cultured day 6 blastocysts caused a rapid increase in the phosphorylation level of both Erk-1 and -2, reaching a maximum increase of about $100 \%$ at $10 \mathrm{~min}$ after insulin exposure and returning to control levels by $60 \mathrm{~min}(10$ and $30 \mathrm{~min}$ vs 60 min: $P<0.05)$.

\section{Insulin receptor and GLUT4 but not GLUT8 mRNA levels are increased by insulin in day 6 rabbit blastocysts}

Insulin treatment almost doubled the level of GLUT4 mRNA but was without effect on GLUT8 mRNA levels (Fig. 2A,B). Culture for $1 \mathrm{~h}$ increased the levels of IR mRNA by about $50 \%$ and insulin treatment for $1 \mathrm{~h}$ led to a further increase of $20 \%$. In the groups exposed to insulin for longer than $2 \mathrm{~h}$ the IR transcript levels declined to control levels (Fig. 2C).

\section{Insulin does not stimulate GLUT4 translocation in day 6 rabbit blastocysts}

GLUT4 immunoreactivity in trophoblast and embryoblast cells following $1 \mathrm{~h}$ insulin stimulation was examined by immunofluorescence. GLUT4 was localized in the perinuclear cytoplasm (Fig. 3B,C). This localization was unchanged by insulin treatment (Fig. 3). It did, however, cause a slight increase in the GLUT4 fluorescence signal (Fig. 3C).

\section{Insulin does not stimulate glucose transport in day 3 rabbit morulae and day 4 blastocysts}

The rate of 3-OMG uptake was higher in blastocysts than in early blastocysts and morulae (blastocysts: $34.7 \pm 4.3$ (mean \pm S.E.M.) $\mathrm{nmol} 3-\mathrm{OMG} / 3 \mathrm{~min} / \mathrm{cm}^{2}$ surface area, $n=91$; early blastocysts: $22.5 \pm 12.9, n=9$; morulae: $16.8 \pm 6.2, n=56$; blastocysts vs morulae: $P<0.05)$. An approximate $50 \%$ increase in glucose uptake rate induced by $166 \mathrm{nM}$ insulin was not significant whilst $16 \mathrm{pM}$ insulin or $1.3 \mathrm{nM}$ IGF-I were clearly ineffective $(P>0.05$; Fig. 4$)$.

\section{Discussion}

The massive stimulation of glucose uptake by insulin in adipose and muscle tissues occurs through a complex receptor signal transduction process promoting the movement of GLUT4 protein from intracellular storage sites to the plasma membrane. In adipocytes and myocytes 


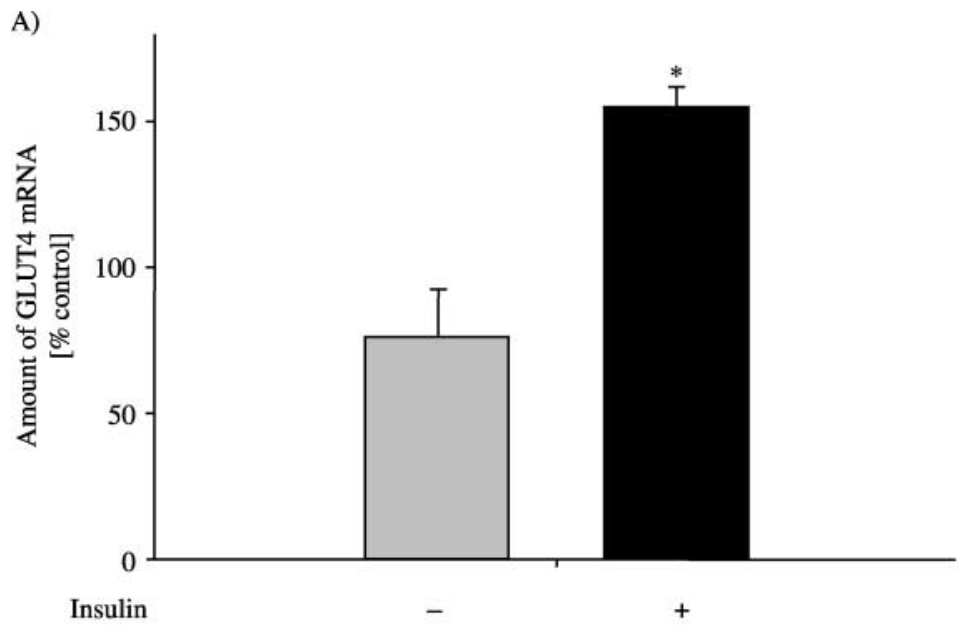

B)

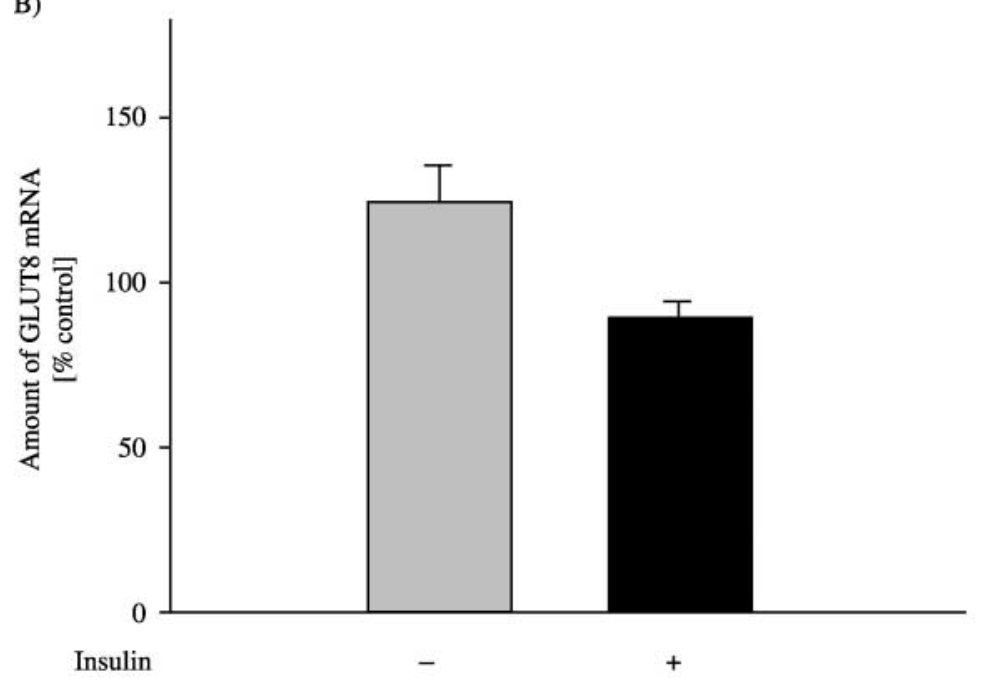

C)

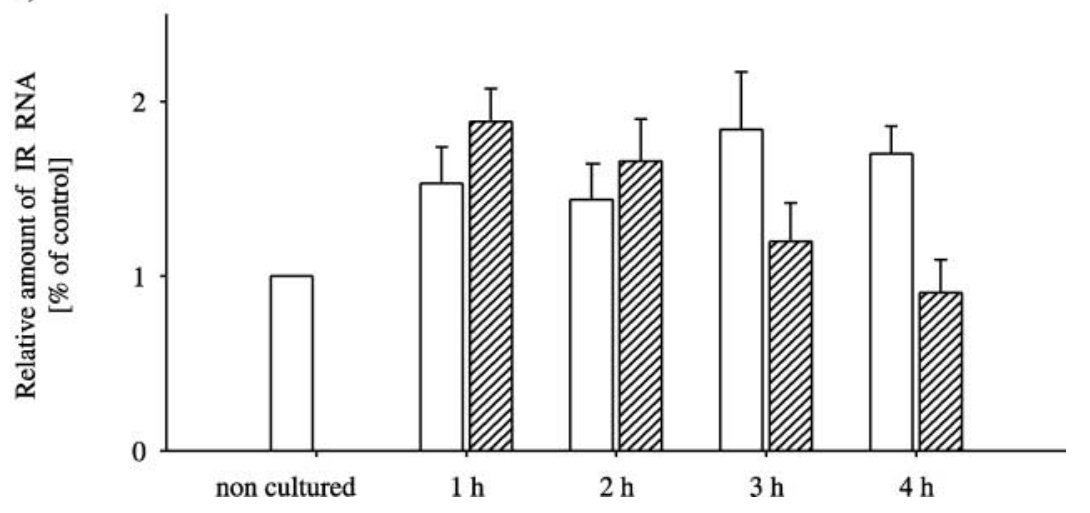

Figure 2 Transcriptional regulation of glucose transporter 4 (GLUT4) and 8 (GLUT8) and insulin receptor (IR) by insulin in day 6 rabbit blastocysts. Day 6 rabbit blastocysts were cultured, in groups of 10 , with or without $170 \mathrm{nM}$ insulin for $1,2,3$ and $4 \mathrm{~h}$. The relative amounts of GLUT4 and IR RNA were quantified by semiquantitative RT-PCR in relation to the housekeeping gene, GAPDH, as described in Materials and Methods. The relative amounts of two experiments are shown. Data from all time points studied (1, 2, 3 and $4 \mathrm{~h}$ ) were combined ( $N=2$ replicates, $n=4$ blastocysts for each experimental group; means \pm S.E.M.). Insulin effects on (A) GLUT4 and (B) GLUT8 transcription reveal a difference between the GLUT isoforms. While transcript numbers of GLUT4 were significantly increased, GLUT8 mRNA levels were unaffected (hatched bars $=$ cultured blastocysts without insulin, solid bars $=$ cultured blastocysts with insulin, control $=$ non-cultured blastocysts set to $100 \%$ ). Asterisks $\left({ }^{*}\right)$ indicate significant differences compared with controls $(P<0.05)$. For IR $(C)$ the means of two individual experiments are shown for each time point studied ( $n=4$ blastocysts for each experimental group in each replicate; means \pm S.E.M.; open bars = cultured blastocysts without insulin, hatched bars = cultured blastocysts with insulin).
GLUT4 translocation is the rate-limiting step of insulinstimulated glucose uptake (Saltiel 2001). In preimplantation embryos GLUT4 expression has been shown for bovine (Navarrete Santos et al. 2000, Augustin et al. 2001), rat (Korgun et al. 2001) and rabbit (Navarrete Santos et al. 2004) blastocysts. The expression data from mouse preimplantation embryos are controversial. Whereas GLUT4 was not found by Hogan and Aghayan and co-authors (Hogan et al. 1991, Aghayan et al. 1992) and insulin stimulation of glucose uptake was only about $40 \%$ suggesting the functional absence of GLUT4 (Pantaleon \& Kaye 1996), we have recently detected GLUT4 mRNA in mouse blastocysts and embryonic stem cells (Tonack et al. 2004). In rabbit blastocysts, GLUT4 is expressed in trophoblast and embryoblast cells. In trophoblast cells of embryos grown in vivo, GLUT4 was localized in the perinuclear compartment and in the cell membrane (Navarrete Santos et al. 2004). This was 


\section{- Insulin 1h}

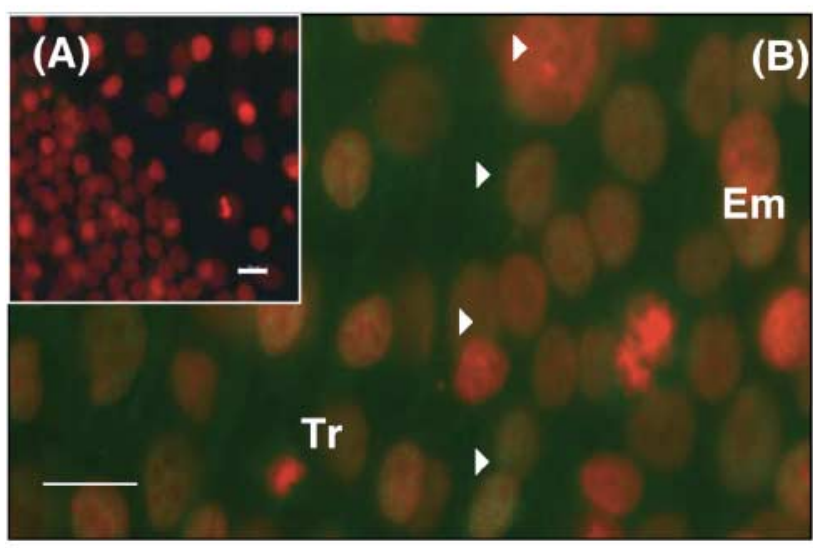

\section{+ Insulin 1h}

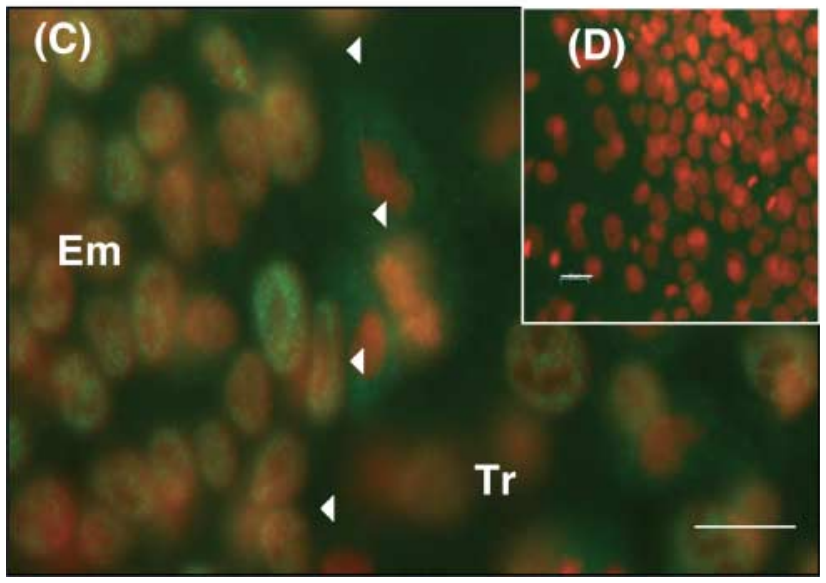

Figure 3 Localization of GLUT4 in day 6 rabbit blastocysts cultured in the presence or absence of insulin. GLUT4 protein was localized perinuclearly in the cytoplasm of trophoblast and embryoblast cells. Detection was performed with a fluorescence-labeled mouse antiGLUT4 (FITC, green color) in day 6 rabbit blastocysts cultured without (B) or with (C) $170 \mathrm{nM}$ insulin for $1 \mathrm{~h}$. A representative staining of a blastocyst from each group in the embryoblast $(\mathrm{Em})$ and trophoblast ( $T r$ ) area is shown. The rim of the embryoblast is marked by white arrowheads. Nuclei were counterstained with 7-AAD (red color). Inserts $\mathrm{A}$ and $\mathrm{D}$ show control reactions for $\mathrm{B}$ and $\mathrm{C}$ respectively. Bars $=20 \mu \mathrm{m}$.

regarded as good evidence for a potentially functional role in the insulin-stimulated uptake of maternal glucose in utero. In order to better understand the cellular and molecular mechanisms of glucose transport and insulin action in preimplantation embryos, in vitro culture of rabbit blastocysts was employed for further studies. We found (i) activation of the IR signaling pathway with (ii) stimulation of the MAPK but not the Akt pathway, (iii) no GLUT4 translocation and no stimulation of glucose uptake, and (iv) an increased GLUT4 and IR transcription in the presence of insulin. These data suggest that insulin stimulates mitogenesis but not glucose transport in rabbit blastocysts.

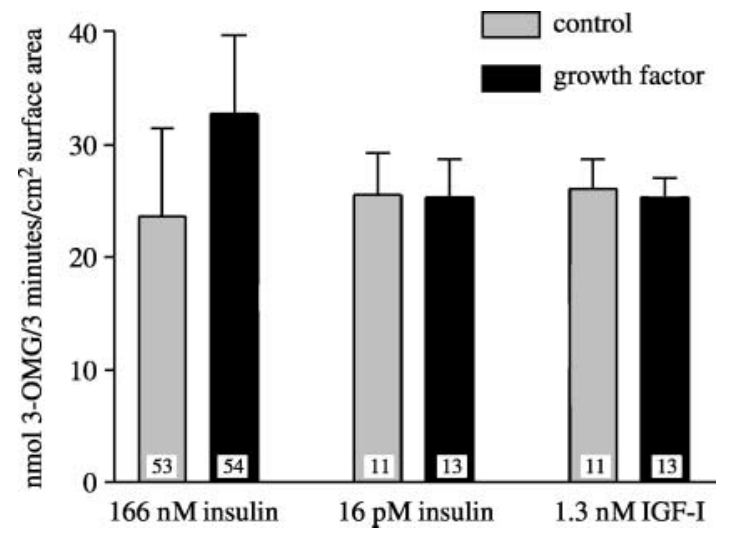

Figure 4 Uptake of 3-OMG in insulin/IGF-I-treated and untreated day 4 rabbit blastocysts. Four-day-old blastocysts were cultured with or without insulin (166 nM, $16 \mathrm{pM})$ or IGF-I (1.3 nM) in glucose-supplemented M2 medium for $1 \mathrm{~h}$. Glucose transport was measured by 3-OMG uptake during a 3-min pulse period. Data are means \pm S.E.M. and are expressed as nmol 3-OMG/3 min/ $/ \mathrm{cm}^{2}$ (see Materials and Methods). The number of embryos is given in each column. Insulin/IGF-I treatment did not increase OMG uptake $(P>0.05)$.

\section{Activation of insulin signaling pathways in rabbit blastocysts by insulin}

It is well established that the insulin-stimulated translocation of GLUT4 to the plasma membrane depends on the production of $\mathrm{PIP}_{3}$ by PI3-K (Fruman et al. 1998). The phosphorylation of the $3^{\prime}$ position recruits and activates proteins containing pleckstrin homology domains, such as $3^{\prime}$ phosphoinositide-dependent kinase-1 (PDK-1) and Akt (Rameh \& Cantley 1999). PDK-1, in turn, phosphorylates and activates downstream effectors including Akt. A role for this pathway in insulin-stimulated GLUT4 translocation has been confirmed. Inhibition of PI3-K using wortmannin and LY294002, and blockade of the PI3-K signaling pathway by dominant-negative mutations inhibited insulin-stimulated GLUT4 translocation and glucose uptake (Cheatham et al. 1994, Okada et al. 1994, Haruta et al. 1995, Kotani et al. 1995). These findings demonstrate that activation of the PI3-K and formation of $\mathrm{PIP}_{3}$ are necessary for GLUT4 translocation. However, some controversial findings exist regarding the role of $\mathrm{PIP}_{3}$ downstream effectors, mainly Akt, and their contribution to insulin-stimulated GLUT4 translocation. Akt is clearly activated in response to insulin in a variety of cell types (Kohn et al. 1996). However, overexpression of dominant-negative Akt mutants has produced divergent results. Whereas expression of the phosphorylation site-deficient Akt did not affect insulin-stimulated GLUT4 translocation, both a kinase dead- and a dual kinase dead-mutant and phosphorylation-deficient construct inhibited translocation (Cong et al. 1997, Kitamura et al. 1998, Wang et al. 1999). The expression of a constitutively active Akt with a membrane targeting sequence promoted GLUT4 translocation in a hormone-independent manner but in a substantially longer time interval than that observed after 
insulin stimulation (Kohn et al. 1996, 1998, Tanti et al. 1997, Foran et al. 1999).

In rabbit blastocysts we did not detect a significant increase in Akt phosphorylation after insulin treatment for up to $2 \mathrm{~h}$, indicating that this pathway was not activated by $170 \mathrm{nM}$ insulin. The antibody used for pAkt detection in the present study would have recognized all three phosphorylated Akt isoforms. The level of Akt phosphorylation was almost identical in insulin-stimulated and control blastocysts at the time points studied after insulin treatment (10 to $120 \mathrm{~min})$, suggesting a basic Akt activation by exogenous (culture conditions, handling) or endogenous factors. For placental JAr cells it has been shown that despite a fourfold Akt activation, GLUT4 translocation, glucose uptake and glycogen synthesis were not stimulated by insulin. Mitogenesis was increased 1.9-fold and accompanied by phosphorylation of the MAPK cascade via Erk1/2 (Boileau et al. 2001). A similar activation of Erk1 and 2 was found in the present study in rabbit blastocysts $10 \mathrm{~min}$ after treatment with $170 \mathrm{nM}$ insulin. Restoration of normal Erk1/2 levels occurred after $1 \mathrm{~h}$ in culture. The activated Erk1/2 cascade preferentially regulates cell growth, differentiation and development (for review see Schaeffer \& Weber 1999). Herrler and co-authors (1998) have previously shown mitogenic and anti-apoptotic effects of insulin in rabbit embryos. Supplementation with IGF-I or insulin improved blastocyst formation producing larger day 3 blastocysts. In day 4 blastocysts addition of increasing amounts of insulin decreased apoptosis and increased cell proliferation in a dose-dependent manner. In cultured bovine embryos, insulin exerted comparable mitogenic and anti-apoptotic activities (Matsui et al. 1995a, b, Byrne et al. 2002, Augustin et al. 2003). Insulin increased blastocyst formation rate and total blastocyst cell number by $33 \%$ and $18 \%$ respectively (Augustin et al. 2003). In cultured mouse embryos insulin increased cell number, mitotic index (Gardner \& Kaye 1991) and blastocyst cell number by specifically increasing inner cell mass (ICM) cell numbers (Harvey \& Kaye 1990, Smith et al. 1993).

\section{Transcriptional regulation of GLUT4 and IR by insulin}

Because glucose transport is a rate-limiting step in glucose metabolism, GLUT4 expression in muscle and adipose is tightly regulated at both the mRNA and protein levels. Both are influenced by numerous hormonal and metabolic signals and physiological states. A major form of regulation involves the translocation of GLUT4 protein from the cytoplasmic vesicles to the plasma membrane in response to insulin (reviewed in Shepherd \& Kahn 1999). Studies in adipose and muscle tissues showed that expression of the GLUT4 glucose transporter is controlled at the level of transcription (Gerrits et al. 1993, Santalucia et al. 1999). It has been shown in adipose, cardiac, and skeletal muscle that insulin-deficient states such as fasting or streptozotocin-induced diabetes resulted in a severe downregulation of GLUT4 messenger RNA and protein (Bourey et al. 1990, Camps et al. 1992, Neufer et al. 1993, Olson et al. 1993, Dombrowski \& Marette 1995, Depre et al. 2000). In our study, insulin treatment increased GLUT4 transcript numbers whereas GLUT4 translocation and glucose uptake were not affected. This finding indicates an involvement of other, so far not clearly known biological processes in GLUT regulation. It is known, however, that GLUT4 expression can be regulated by several transcription factors such as p53 (Schwartzenberg-Bar-Yoseph et al. 2004), myocyte enhancer factor 2A (Knight et al. 2003) and PAX3/forkhead homolog (Armoni et al. 2002).

\section{GLUT4 translocation and stimulation of glucose uptake}

The findings from our glucose uptake study and from GLUT4 immunohistochemistry after insulin treatment point to the same conclusion. GLUT4 localization was not different in embryos cultured for $1 \mathrm{~h}$ in an insulin-free or insulin-supplemented medium. It was localized intracellularly in trophoblast and embryoblast cells. An increase in membrane-associated GLUT4 was not found in the trophoblast cells of insulin-treated rabbit blastocysts and neither insulin nor IGF-I stimulated glucose transport. These and other results underline the significance of ligand concentrations and/or species when comparing studies on IR/IGF-IR effects in preimplantation embryos. For example, both insulin (700 nM) and IGF-I (130 nM) in high concentrations increased apoptosis through the downregulation of the IGF-I receptor in a recent study in mouse blastocysts (Chi et al. 2000). A significant increase $(40 \%)$ in 3-OMG uptake in mouse blastocysts had been achieved with considerably lower IGF-I concentrations (0.17-1.7 pM; Pantaleon \& Kaye 1996) than those employed in the present study, suggesting that in the mouse embryo IGF-I is the key hormone for stimulation of glucose uptake (Pantaleon \& Kaye 1996). The increase in glucose uptake, however, was only moderate compared with insulin effects in myocytes and adipocytes. Insulin action in preimplantation embryos is aimed towards anabolic, mitogenic and anti-apoptotic effects.

In some species the mitogenic and anti-apoptotic effects of insulin and IGF-I were specifically directed towards ICM cells. For example, supplementation with physiological concentrations of IGF-I caused a specific increase in the number of the ICM cells $(1.7 \mathrm{nM}$, human embryos, Lighten et al. 1998; $6.5 \mathrm{nM}$, bovine blastocysts, Sirisathien et al. 2003; $5.2 \mathrm{nM}$, mouse blastocysts, Smith et al. 1993), thus complementing earlier studies with insulin in mice (Harvey \& Kaye 1990). IGF-I and insulin acted as ICMspecific growth factors. The reasons for this phenomenon are unknown. Implications for long-term development have been investigated by culturing two-cell embryos for 2 days in vitro with $170 \mathrm{nM}$ insulin and subsequent 
embryo transfer into foster mothers. Insulin-treated embryos showed an increased fetal growth at day 19 and 20 by 4 to $6 \%$ (Kaye \& Gardner 1999).

In conclusion, despite the stage-specific expression of IR and the insulin-responsive isoforms GLUT4 and GLUT 8, insulin did not stimulate glucose transport in rabbit blastocysts. Analysis of IR signaling indicates that insulin action is directed towards mitogenic rather than metabolic effects during this ontogenetic stage of development in the rabbit. Stimulation of embryonic glucose transport by hormones of the IGF family might not be necessary during this developmental period, perhaps due to an efficient uptake by glucose transporters under the physiological conditions in utero.

\section{Acknowledgements}

We thank Elke Bernhard and Trish Hitchcock for excellent technical assistance and Evelyn Axmann for her excellent help in the preparation of the manuscript. This work was supported in part by grants from the Deutsche Forschungsgemeinschaft (grant FI 306/10-1) and the Australian Research Council (grant LX0211798).

\section{References}

Aghayan M, Rao LV, Smith RM, Jarett L, Charron MJ, Thorens B \& Heyner S 1992 Development expression and cellular localization of glucose transporter molecules during mouse preimplantation development. Development 115 305-312.

Armoni M, Quon MJ, Maor G, Avigad S, Shapiro DN, Harel C, Esposito D, Goshen Y, Yaniv I \& Karnieli E 2002 PAX3/forkhead homolog in rhabdomyosarcoma oncoprotein activates glucose transporter 4 gene expression in vivo and in vitro. Journal of Clinical Endocrinology and Metabolism 87 5312-5324.

Augustin R, Pocar P, Navarrete Santos A, Wrenzycki C, Gandolfi F, Niemann H \& Fischer B 2001 Glucose transporter expression is developmentally regulated in in vitro derived bovine preimplantation embryos. Molecular Reproduction and Development $\mathbf{6 0}$ 370-376.

Augustin R, Pocar P, Wrenzycki C, Niemann H \& Fischer B 2003 Mitogenic and anti-apoptotic activity of insulin on bovine embryos produced in vitro. Reproduction 126 91-99.

Boileau P, Cauzac M, Pereira MA, Girard J \& Hauguel-De Mouzon S 2001 Dissociation between insulin-mediated signaling pathways and biological effects in placental cells: role of protein kinase B and MAPK phosphorylation. Endocrinology 142 3974-3979.

Bourey RE, Koranyi L, James DE, Mueckler M \& Permutt MA 1990 Effects of altered glucose homeostasis on glucose transporter expression in skeletal muscle of the rat. Journal of Clinical Investigation $86542-547$.

Byrne AT, Southgate J, Brison DR \& Leese HJ 2002 Regulation of apoptosis in the bovine blastocyst by insulin and the insulin-like growth factor (IGF) superfamily. Molecular Reproduction and Development 62 489-495.

Camps M, Castello A, Munoz P, Monfar M, Testar X, Palacin M \& Zorzano A 1992 Effect of diabetes and fasting on GLUT-4 (muscle/fat) glucose-transporter expression in insulin-sensitive tissues. Heterogeneous response in heart, red and white muscle. Biochemical Journal 282 765-772.

Cheatham B, Vlahos CJ, Cheatham L, Wang L, Blenis J \& Kahn CR 1994 Phosphatidylinositol 3-kinase activation is required for insulin stimulation of pp70 S6 kinase, DNA synthesis, and glucose transporter translocation. Molecular and Cellular Biology 14 4902-4911.

Chi MM-Y, Schlein AL \& Moley KH 2000 High insulin-like growth factor 1 (IGF-1) and insulin concentrations trigger apoptosis in the mouse blastocyst via down-regulation of the IGF-1 receptor. Endocrinology $1414784-4792$.

Cong LN, Chen H, Li Y, Zhou L, McGibbon MA, Taylor SI \& Quon MJ 1997 Physiological role of Akt in insulin-stimulated translocation of GLUT4 in transfected rat adipose cells. Molecular Endocrinology 11 1881-1890.

Depre C, Young ME, Ying J, Ahuja HS, Han Q, Garza N, Davies PJ \& Taegtmeyer H 2000 Streptozotocin-induced changes in cardiac gene expression in the absence of severe contractile dysfunction. Journal of Molecular and Cellular Cardiology 32 986-996.

Dombrowski L \& Marette A 1995 Marked depletion of GLUT4 glucose transporters in transverse tubules of skeletal muscle from streptozotocin-induced diabetic rats. FEBS Letters 374 43-47.

Fischer B, Mootz U, Denker H-W, Lambertz M \& Beier HM 1991 The dynamic structure of rabbit blastocysts coverings. III. Transformation of coverings under non-physiological developmental conditions. Anatomy and Embryology 183 17-27.

Foran PG, Fletcher LM, Oatey PB, Mohammed N, Dolly JO \& Tavare JM 1999 Protein kinase B stimulates the translocation of GLUT4 but not GLUT1 or transferrin receptors in 3T3-L1 adipocytes by a pathway involving SNAP-23, synaptobrevin-2, and/or cellubrevin. Journal of Biological Chemistry 274 28087-28095.

Fruman DA, Meyers RE \& Cantley LC 1998 Phosphoinositide kinases. Annual Review of Biochemistry 67 481-507.

Gardner HG \& Kaye PL 1991 Insulin increases cell numbers and morphological development in mouse pre-implantation embryos in vitro. Reproduction, Fertility, and Development 3 79-91.

Gerrits PM, Olson AL \& Pessin JE 1993 Regulation of the GLUT4/ muscle-fat glucose transporter mRNA in adipose tissue of insulindeficient diabetic rats. Journal of Biological Chemistry $\mathbf{2 6 8}$ 640-644.

Haruta T, Morris AJ, Rose DW, Nelson JG, Mueckler M \& Olefsky JM 1995 Insulin-stimulated GLUT4 translocation is mediated by a divergent intracellular signaling pathway. Journal of Biological Chemistry $27027991-27994$.

Harvey MB \& Kaye PL 1990 Insulin increases the cell number of the inner cell mass and stimulates morphological development of mouse blastocysts in vitro. Development 110 963-967.

Herrler A, Krusche CA \& Beier HM 1998 Insulin and insulin-like growth factor-I promote rabbit blastocyst development and prevent apoptosis. Biology of Reproduction 59 1302-1310.

Hogan A, Heyner S, Charron MJ, Copeland NG, Gilbert DJ, Jenkins NA, Thorens B \& Schultz GA 1991 Glucose transporter gene expression in early mouse embryos. Development $\mathbf{1 1 3}$ $363-372$.

Kaye PL 1997 Preimplantation growth factor physiology. Reviews of Reproduction 2 121-127.

Kaye PL \& Gardner HG 1999 Preimplantation access to maternal insulin and albumin increases fetal growth rate in mice. Human Reproduction 14 3052-3059.

Kietz S \& Fischer B 2003 Polychlorinated biphenyls affect gene expression in the rabbit preimplantation embryo. Molecular Reproduction and Development 64 251-260.

Kitamura T, Ogawa W, Sakaue H, Hino Y, Kuroda S, Takata M, Matsumoto M, Maeda T, Konishi H, Kikkawa U \& Kasuga M 1998 Requirement for activation of the serine-threonine kinase Akt (protein kinase B) in insulin stimulation of protein synthesis but not of glucose transport. Molecular and Cellular Biology 18 3708-3717.

Knight JB, Eyster CA, Griesel BA \& Olson AL 2003 Regulation of the human GLUT4 gene promoter: interaction between a transcriptional activator and myocyte enhancer factor 2A. PNAS $\mathbf{1 0 0}$ $14725-14730$.

Koerber S, Santos AN, Tetens F, Kuchenhoff A \& Fischer B 1998 Increased expression of NADH-ubiquinone oxidoreductase chain 2 (ND2) in preimplantation rabbit embryos cultured with $20 \%$ 
oxygen concentration. Molecular Reproduction and Development 49 394-399.

Kohn AD, Summers SA, Birnbaum MJ \& Roth RA 1996 Expression of a constitutively active Akt ser/thr kinase in 3T3-L1 adipocyte stimulates glucose uptake and glucose transporter 4 translocation. Journal of Biological Chemistry 271 31372-31378.

Kohn AD, Barthel A, Kovacina KS, Boge A, Wallach B, Summers SA, Birnbaum MJ, Scott PH, Lawrence JC Jr \& Roth RA 1998 Construction and characterization of a conditionally active version of the serine/threonine kinase Akt. Journal of Biological Chemistry 273 11937-11943.

Korgun ET, Demir R, Hammer A, Dohr G, Desoye G, Skofitsch G \& Hahn T 2001 Glucose transporter expression in rat embryo and uterus during decidualization, implantation, and early postimplantation. Biology of Reproduction 65 1364-1370.

Kotani K, Carozzi AJ, Sakaue H, Hara K, Robinson LJ, Clark SF, Yonezawa K, James DE \& Kasuga M 1995 Requirement for phosphoinositide 3-kinase in insulin-stimulated GLUT4 translocation in 3T3-L1 adipocytes. Biochemical and Biophysical Research Communications $209343-348$.

Le Roith D \& Zick Y 2001 Recent advances in our understanding of insulin action and insulin resistance. Diabetes Care 24 588-597.

Lighten AD, Moore GE, Winston RM \& Hardy K 1998 Routine addition of human insulin-like growth factor-I ligand could benefit clinical in-vitro fertilization culture. Human Reproduction 13 3144-3150.

Lindenau A \& Fischer B 1994 Effects of oxygen concentration in the incubator's gas phase on the development of cultured preimplantation embryos. Theriogenology 41 889-898.

Matsui M, Takahashi Y, Hishinuma M \& Kanagawa H 1995a Insulin and insulin-like growth factor-I (IGF-I) stimulate the development of bovine embryos fertilized in vitro. Journal of Veterinary Medicine Science 57 1109-1111.

Matsui M, Takahashi Y, Hishinuma M \& Kanagawa H 1995b Stimulatory effects of insulin on the development of bovine embryos fertilized in vitro. Journal of Veterinary Medicine Science $\mathbf{5 7}$ $331-336$.

Navarrete Santos A, Korber S, Kullertz G, Fischer G \& Fischer B 2000 Oxygen stress increases prolyl cis/trans isomerase activity and expression of cyclophilin 18 in rabbit blastocysts. Biology of Reproduction 62 1-7.

Navarrete Santos A, Tonack S, Kirstein M, Kietz S \& Fischer B 2004 Two insulin-responsive glucose transporter isoforms and the insulin receptor are developmentally expressed in rabbit preimplantation embryos. Reproduction.

Neufer PD, Carey JO \& Dohm GL 1993 Transcriptional regulation of the gene for glucose transporter GLUT4 in skeletal muscle. Effects of diabetes and fasting. Journal of Biological Chemistry 268 $13824-13829$.

Okada T, Kawano Y, Sakakibara T, Hazeki O \& Ui M 1994 Essential role of phosphatidylinositol 3-kinase in insulin-induced glucose transport and antilipolysis in rat adipocytes. Studies with a selective inhibitor wortmannin. Journal of Biological Chemistry 269 3568-3573.

Olson AL, Liu ML, Moye-Rowley WS, Buse JB, Bell GI \& Pessin JE 1993 Hormonal/metabolic regulation of the human GLUT4/muscle-fat facilitative glucose transporter gene in transgenic mice. Journal of Biological Chemistry 268 9839-9846.

Pantaleon M \& Kaye PL 1996 IGF-I and insulin regulate glucose transport in mouse blastocysts via IGF-I receptor. Molecular Reproduction and Development 44 71-76.

Pantaleon M, Harvey MB, Pascoe WS, James DE \& Kaye PL 1997 Glucose transporter GLUT3: ontogeny, targeting, and role in the mouse blastocyst. PNAS 94 3795-3800.
Pantaleon M, Jericho H, Rabnott G \& Kaye PL 2003 The role of insulin-like growth factor II and its receptor in mouse preimplantation development. Reproduction, Fertility, and Development 15 37-45.

Patki V, Buxton J, Chawla A, Lifshitz L, Fogarty K, Carrington W, Tuft R \& Corvera S 2001 Insulin action on GLUT4 traffic visualized in single 3T3-I1 adipocytes by using ultra-fast microscopy. Molecular Biology of the Cell 12 129-141.

Pessin JE, Thurmond DC, Elmendorf JS, Coker KJ \& Okada S 1999 Molecular basis of insulin-stimulated GLUT4 vesicle trafficking. Location! Location! Location! Journal of Biological Chemistry 274 2593-2596.

Rameh LE \& Cantley LC 1999 The role of phosphoinositide 3-kinase lipid products in cell function. Journal of Biological Chemistry 274 8347-8350.

Rea S \& James DE 1997 Moving GLUT4: the biogenesis and trafficking of GLUT4 storage vesicles. Diabetes 46 1667-1677.

Robinson DH, Smith PR \& Benos DJ 1990 Hexose transport in preimplantation rabbit blastocysts. Journal of Reproduction and Fertility $891-11$.

Saltiel AR 2001 New perspectives into the molecular pathogenesis and treatment of type 2 diabetes. Cell 104 517-529.

Santalucia T, Boheler KR, Brand NJ, Sahye U, Fandos C, Vinals F, Ferre J, Testar X, Palacin M \& Zorzano A 1999 Factors involved in GLUT-1 glucose transporter gene transcription in cardiac muscle. Journal of Biological Chemistry 274 17626-17634.

Schaeffer HJ \& Weber MJ 1999 Mitogen-activated protein kinases: specific messages from ubiquitous messengers. Molecular and Cellular Biology 19 2435-2444.

Schultz GA, Hogan A, Watson AJ, Smith RM \& Heyner S 1992 Insulin, insulin-like growth factors and glucose transporters: temporal patterns of gene expression in early murine and bovine embryos. Reproduction, Fertility, and Development 4 361-371.

Schwartzenberg-Bar-Yoseph F, Armoni M \& Karnieli E 2004 The tumor suppressor p53 down-regulates glucose transporters GLUT1 and GLUT4 gene expression. Cancer Research 64 2627-2633.

Shepherd PR \& Kahn BB 1999 Glucose transporters and insulin action - implications for insulin resistance and diabetes mellitus. New England Journal of Medicine 341 248-257.

Sirisathien S, Hernandez-Fonseca HJ \& Brackett BG 2003 Influences of epidermal growth factor and insulin-like growth factor-I on bovine blastocyst development in vitro. Animal Reproduction Science 77 21-32.

Smith RM, Garside WT, Aghayan M, Shi CZ, Shah N, Jarett L \& Heyner S 1993 Mouse preimplantation embryos exhibit receptormediated binding and transcytosis of maternal insulin-like growth factor I. Biology of Reproduction 49 1-12.

Tanti JF, Grillo S, Gremeaux T, Coffer PJ, Van Obberghen E \& Le Marchand-Brustel Y 1997 Potential role of protein kinase B in glucose transporter 4 translocation in adipocytes. Endocrinology $1382005-2010$.

Tonack S, Fischer B \& Navarrete Santos A 2004 Expression of the insulin-responsive glucose transporter isoform 4 in blastocysts of C57/BL6 mice. Anatomy and Embryology 208 225-230.

Wang Q, Somwar R, Bilan PJ, Liu Z, Jin J, Woodgett JR \& Klip A 1999 Protein kinase B/Akt participates in GLUT4 translocation by insulin in L6 myoblasts. Molecular and Cellular Biology 19 4008-4018.

Received 13 February 2004

First decision 24 May 2004

Revised manuscript received 30 June 2004

Accepted 9 July 2004 